\title{
We Don't Play As We Think, But We Think As We Play: Evidence for the Psychological Impact of In-Game Actions
}

\author{
Barrett R. Anderson \\ UC Santa Cruz \\ Santa Cruz, California \\ barander@ucsc.edu
}

\author{
Christopher R. Karzmark \\ UC Santa Cruz \\ Santa Cruz, California \\ ckarzmar@ucsc.edu
}

\author{
Noah Wardrip-Fruin \\ UC Santa Cruz \\ Santa Cruz, California \\ nwardrip@ucsc.edu
}

\begin{abstract}
Games are able to convey meaning that influences players' beliefs and attitudes via their mechanics (aka "procedural rhetoric"), but recent work suggests that this is likely to be effective only when combined with traditional ways of conveying meaning (e.g., music, imagery, narrative, etc.). To investigate the specific component of rhetorical influence that comes from game mechanics, we constructed a city management strategy game that allowed us to independently vary narrative framing and game rules. We found that players perceived this game to be making an argument, but that player interpretations of this argument and the game's influence on their attitudes were not necessarily consistent with our intended message. When players had the option to make policy choices within the game, their decisions appeared to be driven more by what game mechanics rewarded rather than by their real-world policy preferences. However, the actions that they took within the game did predict changes in those policy preferences after play. This was true only when the narrative framing of the game matched the real world policy context. This implies that procedural rhetoric is most effective when supported by other ways of conveying meaning, and that understanding the psychological impact of game mechanics requires paying attention to the moment to moment choices that players make within a game.
\end{abstract}

\section{CCS CONCEPTS}

- Applied computing $\rightarrow$ Psychology; Computer games.

\section{KEYWORDS}

Procedural Rhetoric, Persuasive Games, Psychology, Empirical Research

\section{ACM Reference Format:}

Barrett R. Anderson, Christopher R. Karzmark, and Noah Wardrip-Fruin. 2020. We Don't Play As We Think, But We Think As We Play: Evidence for the Psychological Impact of In-Game Actions. In International Conference on the Foundations of Digital Games (FDG '20), September 15-18, 2020, Bugibba, Malta. ACM, New York, NY, USA, 11 pages. https://doi.org/10.1145/3402942. 3402967

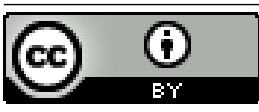

This work is licensed under a Creative Commons Attribution International 4.0 License. FDG '20, September 15-18, 2020, Bugibba, Malta

(C) 2020 Copyright held by the owner/author(s).

ACM ISBN 978-1-4503-8807-8/20/09.

https://doi.org/10.1145/3402942.3402967

\section{BACKGROUND}

Games are capable of conveying meaning via their interactive systems, in a form of communication dubbed "procedural rhetoric" [6]. A recent investigation determined that players of persuasive games are generally aware of those games' rhetorical content, and when this procedural rhetoric is combined with the ways of conveying meaning that games have in common with other forms of media (e.g., aspects of media such as visual art, narrative, etc.), they can be effective at changing players' beliefs and attitudes [1]. We refer to this impact on a player's beliefs and attitudes as the psychological reality of procedural rhetoric, to contrast it with interpretations of rhetorical meaning by scholars and games critics. For the present study we created a rhetorical game which allows us to independently manipulate either the game mechanics, or visual and narrative elements, in order to tease apart their distinct effects.

The primary contributions of this work are as follows:

PC1 To supplement humanistic games criticism with an empirical approach to understanding the impact of game experiences.

PC2 To provide empirical insight about the relationship between in-game actions and an individual's values and opinions.

A secondary contribution is the application of a recently developed scale to quantify a game's perceived rhetorical content. These contributions will primarily be of value to game creators and scholars.

\subsection{Meaning from Game Mechanics}

Bogost [6, p. ix] defined procedural rhetoric as "the art of persuasion through rule-based representations and interactions rather than the spoken word, writing, images, or moving pictures." The distinct contribution of game rules can be made clearer when the rules produce a feeling of "ludonarrative dissonance" [14] which occurs when they contradict the message of other game elements.

Any rule-based system that is grounded in the real world can be read as making a claim about or a caricature of that aspect of reality. The original purpose of the boardgame that became Monopoly, as an economically grounded educational tool [27], is an example of such an effort. The game's subsequent history and its reinterpretations are an illustration of the challenges and complexities of the rulebased approach to persuasion. The SimCity effect, where the game "through play, brings the player to an accurate understanding of the system's internal operations" [33, p. 2] describes how a player internalizes a model of the world that is articulated in a game. There is a danger here because game world models, not necessarily intended to reflect reality, come with their own sets of biases. The rules of SimCity itself, for example, implicitly support a specific model of urban planning by only allowing certain kinds of cities to thrive [26]. If a player comes to an intuitive understanding of 
the hidden relationships as they explore this model through play, might they not also apply that understanding to their interpretation of the game's real world analogs? This appears even more likely for something like a city, a complex and unwieldy collection of overlapping systems that often inspire modeling [7, 24].

Procedural rhetoric is not an uncontested notion. Bogost has been criticized for emphasizing the communicative power of rulebased processes, without accounting for the way that those elements are inseparable from other aspects of the game experience[3, 29]. Our own work has found empirical evidence supporting the notion that game mechanics alone are insufficient for creating unambiguous rhetoric [1]. Players also have more variable experiences with games, based on their different choices, skills, and life experiences, all of which can lead to different readings [32]. The variability of readings from person to person (and play session to play session) qualifies any interpretation. Nonetheless, an experimental approach can provide a statistical picture of typical player experiences.

\subsection{Procedural Rhetoric and Analogical Transfer}

Analogical transfer is the ability to apply information from an older solved problem to a newer, seemingly unrelated, one. While this is often presented in popular culture as a flash of brilliant insight, it is also an ordinary part of human cognition. Researchers describe two related problems where this kind of transfer is possible as having an underlying "structural similarity," even when their superficial "surface similarity" is low [17]. Having structural (or deep) similarity means that the elements in the source problem can be mapped, one-to-one, to elements in the target problem, and that this mapping generally preserves the relationships between these elements. Having surface similarity means that both the source and target problems are in ostensibly the same domain (e.g., politics, medicine, etc.). The ability to understand a new situation as a variation on a familiar one has been described as a central pillar of human cognition $[4,15,16]$.

Despite clear advantages of perceiving connections from one domain to another for problem solving, research suggests that analogical transfer is not very likely unless surface similarity between problem domains is high $[17,25]$, or participants are explicitly cued with references to their earlier solutions [12]. This difference in performance has been called the "analogical paradox" [10]. The findings above paint a discouraging picture for the potential of transfer (or learning) from a narrative description, but research suggests that transfer from an interactive system (and therefore from game mechanics) may be a different matter [9].

\subsection{Transfer from Metaphorical Language}

While it is difficult to get analogical transfer to occur without explicit cues, in contrast metaphorical language sometimes has an unexpected influence $[5,19,20]$. The embodied cognition argument posits that this is because the metaphorical content of ordinary language influences our thoughts and actions even when we are not consciously aware of it [21]. In one study of metaphorical transfer participants read a newspaper article that described a crime problem in a city, using language that either described crime as a beast, or as a virus. After, they were likely to align their policy preferences with those suggested by the metaphorical framing of the article [30]. This change in preferences happens even without any awareness on the part of the readers of the metaphorical connection implied in the passage [31]. It is important here to note that these metaphorical descriptions are not in any way unnatural. Close readings newspaper articles often reveal a variety of implicit metaphors [18, 23, 28]. If the thoughts and attitudes about complex and abstract ideas like crime are subject to the subtle influence of ordinary language choices, it seems likely that they are also subject to influence from experiences with interactive systems.

The current study, inspired by this examination of the covert influence of natural language metaphors on reasoning, extends this work to examine the potential influence of interactive game systems. As in the metaphorical language study described above, we attempted to influence real world policy preferences.

\subsection{Research questions.}

To investigate the influence of our rhetorical game, we asked the following four questions:

RQ1 Will our participants identify the rhetorical game they are asked to play as containing an argument?

RQ2 What argument will participants perceive, and will it match the argument that we intended?

RQ3 Will differences in game mechanics or in narrative content change the perceived argument?

RQ4 Will playing the game result in any change in the participant's attitude or values, as it relates to the game's content?

For RQ1, we hypothesized that participants would be aware that the game they are playing has rhetorical intent, both because of the research context in which the game is presented and because participants have demonstrated this awareness for other rhetorical games [1]. By research context we mean that the game is presented to them as participants in a psychological study, and it is presented after they have answered questions about their own beliefs that are also related to the game's content.

We hypothesized, for RQ2, that participants would be aware of the argument that we intended. While there are always different possible readings, the game that we created for this study was critiqued, playtested, and iterated on with rhetorical intent in mind from its conception. Previous work exploring the influence of rhetorical games [1] did find differences in the specific arguments that players perceived, but more so for games with a greater degree of abstraction than ours (i.e., those attempting to convey their meaning solely or primarily through mechanics).

Similarly, for RQ3, we hypothesized that differences in the game's mechanical or thematic content would lead to different interpretations of the game's argument, based on our work prototyping and playtesting of different versions of our game. This is complicated somewhat by the observation[1] that, for more abstract games, participants demonstrated awareness of the context of the game's argument but not of the specific position that the authors intended, or that the critics perceived.

For RQ4, we did not hypothesize any explicit changes in participants' behavior or values after playing the game. While it is possible that participants will be aware of and influenced by the game they play in the course of this study, personal attitudes and 
values (in this case expressed as policy preferences) may be relativly stable. Behavior is more difficult to observe, and in the context of this study consists solely of actions taken in-game. Unfortunately, interpretation of these actions is confounded by the context of the game itself. Based on our understanding of analogical transfer from systems, and of the influence of metaphorical language, it also seems plausible that games will exert a covert influence on players. This has theoretical and practical implications, for both how we understand analogical transfer and for the analysis and development of meaningful games.

\section{METHODS}

\subsection{Participants}

Participants included 110 undergraduates enrolled in psychology courses, recruited from a university psychology subject pool, ranging from 18-33 years of age $(M=21.00, S D=2.73)$ including 82 who identified as female (74.54\%) and 17 who identified as male (15.45\%). Slightly more than one third of participants identified as Latinx ( $\mathrm{n}=15,34.88 \%$ ), and slightly less than one third identified as Asian ( $\mathrm{n}=13,30.23 \%)$ The remaining participants identified as White $(\mathrm{n}=9,20.93 \%)$, Multiethnic $(\mathrm{n}=5,11.63 \%)$, and Black $(\mathrm{n}=$ $1,2.33 \%$ ). While women are over-represented in this sample compared to the general public, recent industry reports have identified adult women as the single largest demographic group (36\%) of all videogame players [2]. Only about a quarter of our participants indicated agreement with the statement 'I consider myself a gamer.' ( $\mathrm{n}=24,25.00 \%$ ). Because of its potential relevance to the content of the persuasive games in this study we also asked participants to report their political identification at the end of the experiment. This work took place at a university in the US, and a slight majority of participants identified their political affiliation as Democrat (n $=67,64.47 \%$ ), with the remainder roughly evenly divided between Republican $(\mathrm{n}=10,9.60 \%)$, Other $(\mathrm{n}=15,15.38 \%)$, and None $(\mathrm{n}=$ $11,10.57 \%)$

\subsection{Materials}

2.2.1 Crime Metaphor Game. For the present study, we developed a game with an intentional procedural rhetoric, which we referred to as our Crime Metaphor Game. This game was inspired in part by the board game Pandemic [22], which included mechanics that modeled the spread of a "virus" through a network of cities. Our Crime Metaphor Game was substantially different in several ways (e.g., computer-based, single-player, with different rulesets for modeling the spread of crime). There is no canonically correct procedural reading [32], but to answer RQ2 we developed expectations based on our own understanding of procedural rhetoric and grounded in research into the impact of metaphorical language [31].

We created four distinct versions of this city management game, by combining two sets of mechanics with three different narrative framings. One version of the game was about containing escaped wild beasts, this was the "Beast" version. Another, with disctinct mechanics, was about preventing the spread of a virus. This was the "Virus" version. The final two versions shared a narrative framing about managing crime, but one used mechanics from the "Beast" version and the other mechanics from the "Virus" version. These

\begin{tabular}{lll} 
Game Version & Narrative Theme & Mechanics \\
\hline Beast & Beast & Beast \\
Crime-as-a-Beast & Crime & Beast \\
Virus & Virus & Virus \\
Crime-as-a-Virus & Crime & Virus \\
\hline
\end{tabular}

Table 1: Narrative themes and mechanics for each version of the Crime Metaphor Game.

variations were the "Crime-as-a-Beast" and "Crime-as-a-Virus" versions (See Table 1).

2.2.1.2 All game versions. Participants were presented with a grid representing a city on the left hand side of the screen (See Fig.1), where each square in the grid is one neighborhood. On the right hand side of the screen a chart tracks overall progress (mayhem/virus/crime level over time). Players can also see, based on the opacity of a red overlay, how bad the current problem is in each individual neighborhood. (Pretesting indicated that these levels are visually distinguishable via non-color cues.) The lower left hand side of the screen summarizes the four possible actions available to players, including a general description and resource cost. In each of the narrative framings (Beast, Virus, Crime) these actions included two "prevention" type options (i.e., after school programs, or vaccinations) and two harsher "enforcement" type options (i.e., police raid, quarantine). The distinction between these types was not explicitly presented to the player with any on-screen indicators. The game is played in a series of rounds, with each round ending once a player has spent all of their resources on actions. The game does not allow actions which have no impact on the city map (e.g., an action to remove crime from a neighborhood that is already at zero crime), responding to attempts with a warning message and not expending any player resources. At the end of each round mayhem/virus/crime grows or spreads, based on the mechanics of the current game version. The game ends either after eight rounds, or (less frequently) as soon as the player has eliminated all mayhem/virus/crime from the city.

2.2.1.3 Comparison of game versions. The major mechanical differences between the two "Virus" and "Crime-as-a-Virus" versions of our Crime Metaphor Game and the two "Beast" and "Crime-asa-Beast" versions were in what player actions did, and in how the current problem (Mayhem/Virus/Crime level) spread. In the "Beast" and "Crime-as-a-Beast' versions of the game, all crime or mayhem spread from beast/crook figures that existed at a given location on the city map. Player enforcement actions could harm beasts/crooks (causing them to become wounded/afraid), and eventually eliminate them entirely. However, these actions would also make any neighborhoods they were conducted in worse. In contrast, prevention actions could reduce the current problem level, but would not have any effect on the beasts/crooks. At the end of the player's turn each beast/crook remaining would make the problem worse in their own neighborhood, and possibly move on to an adjacent neighborhood.

In the "Virus" and "Crime-as-a-Virus" game versions, players' enforcement actions eliminated or reduced the problem in the targeted neighborhoods, at the cost of making them more likely to become worse on future turns. In contrast, the prevention actions 


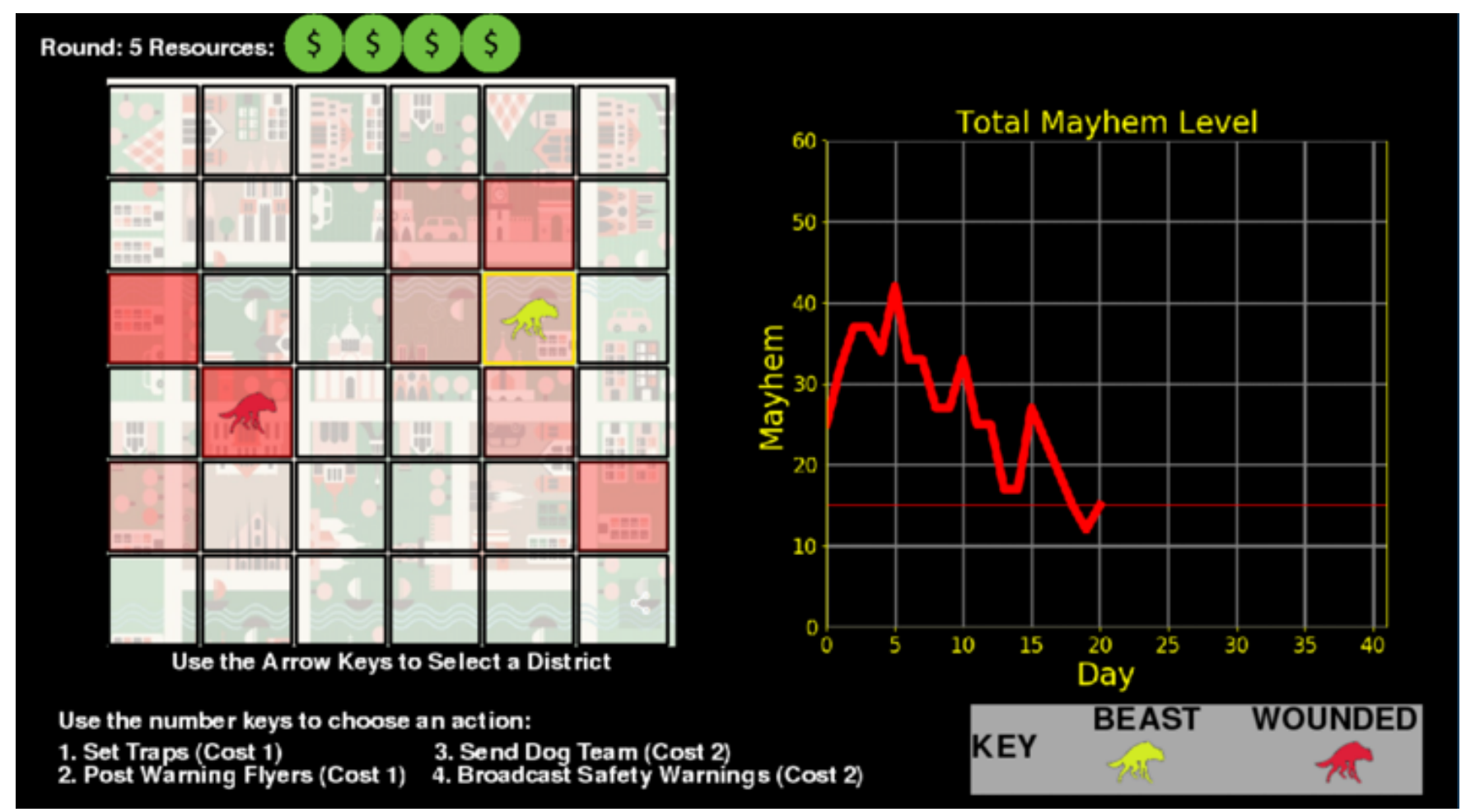

Figure 1: Crime Metaphor Game layout for the Beast version. See city map (left), feedback graph (right) and player actions (bottom left)

reduced the chance of any neighborhood becoming worse, but did nothing to mitigate current problems. Between player turns, a fixed amount of additional crime/virus appeared in random map locations. Independently, each of the neighborhoods that had been put at risk by an enforce action also had a small chance to become worse, which increased for each time they had been impacted by those actions (See Table 2).

2.2.1.4 Anticipated Rhetoric. While we acknowledge that each player's reading and interpretation of our Crime Metaphor Game might vary, we did create every version of the game with explicit rhetorical intent (See Table 2). We attempted to translate the metaphorical narrative framings in the Thibodeau \& Boroditsky (2013)[31] study described above into their procedural rhetoric equivalents. Our intent was for players in the "Crime-as-a-Virus" version of our Crime Metaphor Game to see the game as making a pro-prevention argument, and for those in the "Crime-as-a-Beast" to see the game as making a pro-enforcement argument. This was achieved by varying the effectiveness of prevention and enforcement themed actions between versions.

Based on our playtesting, the ideal play in the "Beast" or "Crimeas-a-Beast" version of the Crime Metaphor Game was initial strong enforcement actions followed by a small number of prevention actions. These versions of the game were winnable, and crime was a solvable problem. In contrast, the best possible outcomes in the "Virus" and "Crime-as-a-Virus" game versions were between stability and slight improvement. In these versions of the game, no matter how well the player performed, crime was always going to be present to some degree. While strong enforcement actions were initially helpful, their ongoing negative impact outweighed these benefits. Differences in winnability and the consequences of ideal play were consistent with our rhetorical intentions. "Crime-as-aBeast" implies that crime is an acute problem that can be definitively solved with enforcement actions. "Crime-as-a-Virus" implies that crime is a chronic problem, and while some choices can make things better or worse it does not have any permanent solution.

Extensive feedback that helped us in the development of this game was provided by game scholars and game creators. While the game was improved immeasurably based on this feedback, these experts presumably had high levels of procedural literacy. Our participants' interpretations are presumably more indicative of the experiences of a general audience.

2.2.2 Questionnaires. All participants completed questionnaires about their attitudes, beliefs, and policy preferences related to our game's rhetorical intent (before and after play), about their gameplay experiences, and about their perception of the game's rhetorical content. Participants were also asked about their attitudes toward media, and to provide other basic demographic information.

Prevention vs. Enforcement Preference Questionnaires. To probe the effectiveness of our rhetorical game we adapted questions from the language related study described above[31]. This included questions that asked participants to rank the priority that should be given to several possible approaches to dealing with crime that could be categorized as more enforcement or prevention oriented 


\begin{tabular}{|c|c|c|c|c|c|}
\hline $\begin{array}{l}\text { Game } \\
\text { Version }\end{array}$ & $\begin{array}{l}\text { Enforcement } \\
\text { Action Names }\end{array}$ & $\begin{array}{l}\text { Enforcement } \\
\text { Action Effects }\end{array}$ & $\begin{array}{l}\text { Prevention } \\
\text { Action Names }\end{array}$ & $\begin{array}{l}\text { Prevention } \\
\text { Action Effects }\end{array}$ & $\begin{array}{l}\text { Virus/Mayhem/Crime } \\
\text { Spreads }\end{array}$ \\
\hline Beast & $\begin{array}{l}\text { Set Traps } \\
\text { Send Dog Team }\end{array}$ & $\begin{array}{l}\text { Harm/Remove Beasts } \\
\text { Increase Mayhem }\end{array}$ & $\begin{array}{l}\text { Post Warning Flyers } \\
\text { Broadcast Safety } \\
\text { Warnings }\end{array}$ & Reduce Mayhem & From Beasts \\
\hline Virus & $\begin{array}{l}\text { Restrict Travel } \\
\text { Implement } \\
\text { Quarantine }\end{array}$ & $\begin{array}{l}\text { Remove Virus } \\
\text { Make neighborhoods } \\
\text { unsafe }\end{array}$ & $\begin{array}{l}\text { Health Education } \\
\text { Vaccination Clinic }\end{array}$ & $\begin{array}{l}\text { Make } \\
\text { neighborhoods } \\
\text { safe }\end{array}$ & $\begin{array}{l}\text { At Random } \\
\text { More likely in } \\
\text { unsafe } \\
\text { Neighborhoods }\end{array}$ \\
\hline $\begin{array}{l}\text { Crime-as- } \\
\text { a-Beast }\end{array}$ & $\begin{array}{l}\text { Conduct Raids } \\
\text { Increase Patrols }\end{array}$ & $\begin{array}{l}\text { Harm/Remove } \\
\text { Crooks } \\
\text { Increase Mayhem }\end{array}$ & $\begin{array}{l}\text { Neighborhood Watch } \\
\text { After School Program }\end{array}$ & Reduce Crime & From Crooks \\
\hline $\begin{array}{l}\text { Crime-as- } \\
\text { a-Virus }\end{array}$ & $\begin{array}{l}\text { Conduct Raids } \\
\text { Increase Patrols }\end{array}$ & $\begin{array}{l}\text { Remove Crime } \\
\text { Make Neighborhoods } \\
\text { unsafe }\end{array}$ & $\begin{array}{l}\text { Neighborhood Watch } \\
\text { After School Program }\end{array}$ & $\begin{array}{l}\text { Make } \\
\text { neighborhoods } \\
\text { safe }\end{array}$ & $\begin{array}{l}\text { At Random } \\
\text { More likely in } \\
\text { unsafe } \\
\text { Neighborhoods }\end{array}$ \\
\hline
\end{tabular}

Table 2: Differences in action names and effects between versions of the Crime Metaphor Game.

(e.g., "Increase police patrols that look for criminals," and "Expand economic welfare programs and create jobs," etc.). We also asked participants how resources should be distributed between these priorities. Additionally, we adapted questions from existing questionnaires on attitudes toward crime [8] that looked for individual vs. external attribution (e.g., "Once a criminal, always a criminal" vs. "Poverty and inequality in society are responsible for much of crime") and punitive vs. rehabilitative goals (e.g., "More emphasis should be placed on keeping criminals behind bars" vs. "If judges would divert more people from prisons into rehabilitation programs, there would be less crime.")

Game Experience Questions. For all games we asked questions related to the game experience itself. This included asking the participant the degree to which they felt they understood and enjoyed the game they had just played, qualitative questions about their interpretation of the games' meaning, and responses to a scale intended to provide a more quantitative measure of their perception of the game's rhetorical content. For each game, all participants were asked what they thought the game was about, if they thought the game was making an argument, and to describe the argument that the game was making.

Media Relationship Questions. Because we suspected that an individual participant's relationship to media, and particularly to games, might have a moderating effect on their perception of and reaction to a game's rhetoric, we also asked participants questions about this relationship. These questions were placed after all game play and responses to avoid any demand characteristics. Degree of agreement with statements such as "I think about the meaning

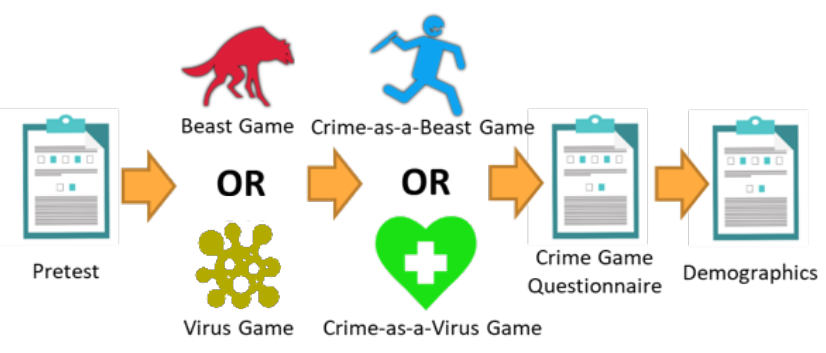

Figure 2: Summary of the study procedure.

of the games I play," and "When I'm playing a game, I just want to have fun." (reverse coded) were combined to create a measure of media criticality. We also asked participants to indicate the degree to which they identified as a "gamer" and for the number of hours each week they played any kind of (non-sports ${ }^{1}$ ) games.

2.2.3 Demographic Questions. The final questionnaire that players completed in this study asked them to provide their age, gender, ethnicity, and political affiliation.

\subsection{Procedure}

After arriving and providing informed consent, participants were asked to complete a battery of questionnaires to establish baseline values related to their policy preferences regarding issues addressed

${ }^{1}$ Our intent with this qualification was the exclusion of physical sports, not the exclu-
sion of sports-themed videogames, but that was not explicitly stated to participants. 
in our Crime Metaphor Game. They were then assigned to play the Virus or Beast version of the game, followed by either the the Crime-as-a-Beast or the Crime-as-a-Virus version. This repetition of game versions is the most likely way to overcome the "analogical paradox" [10] and achieve transfer effects of any kind. Playing the two versions of the game in succession this way also allowed us to observe transfer of learned strategies from the first game (Beast or Virus) to the second (Crime-as-a-Beast or Crime-as-a-Virus) when the game mechanics were identical and when they varied, to aid in distinguishing between game mechanical and thematic influences. This resulted in four experimental conditions:

- Beast -> Crime-as-a-Beast

- Beast -> Crime-as-a-Virus

- Virus -> Crime-as-a-Beast

- Virus -> Crime-as-a-Virus

After playing both games participants responded to a questionnaire about their game experiences, were again asked to respond to questions about their policy preferences related to the issues addressed by the game. Finally, participants completed a questionnaire asking about their experience with and attitudes towards games and media in general, ending with a brief demographic survey. The procedure is summarized in Fig. 2.

\section{RESULTS}

Our findings are organized around answering each of the research questions listed above.

\subsection{Q1. Did our participants identify the game we asked them to play as containing an argument?}

3.1.1 Yes or No. Participants were asked whether they felt that the game that they had just played contained an argument. When asked directly, participants overwhelmingly said "Yes" ( $n=37,90.24 \%)$.

3.1.2 Rhetorical Content Scale. Responses on the perceived rhetorical content scale (PR scale) were evaluated in comparison to ratings from a previous study using this scale [1]. Results for our Crime Metaphor Game $(M=3.6, S D=.48)$ fell between $L I M(M=3.26$, $S D=.97)$, an abstract persuasive game, and September 12 th $(M=$ $3.79, S D=.99$ ), a persuasive game that combines mechanics with traditional rhetoric, and well above Threes $\mathcal{F S}(M=3.79, S D=.99)$, a math puzzle game included as a non-rhetorical control (See Fig. 3). We observed no differences in rhetorical content rating based on game condition, $F(3,96)=1.50, p=.221$, (See Fig. 4).

\subsection{Q2: What argument did participants perceive, and did it match the argument that we intended?}

3.2.1 Coding Qualitative Responses. After playing each game and indicating whether or not it contained an argument, participants were asked to describe in their own words what that argument was. These responses were then coded into categories, which were generated using a grounded-theory based process [13]. Each response was coded for whether it belonged in each category independently, so a single response might appear in more than one category. In

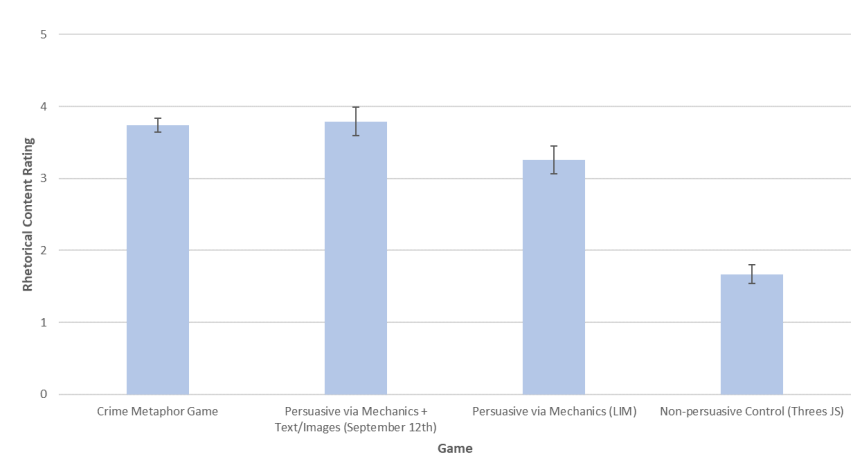

Figure 3: Rhetorical content rating of the Crime Metaphor Game was similar to other persuasive games.

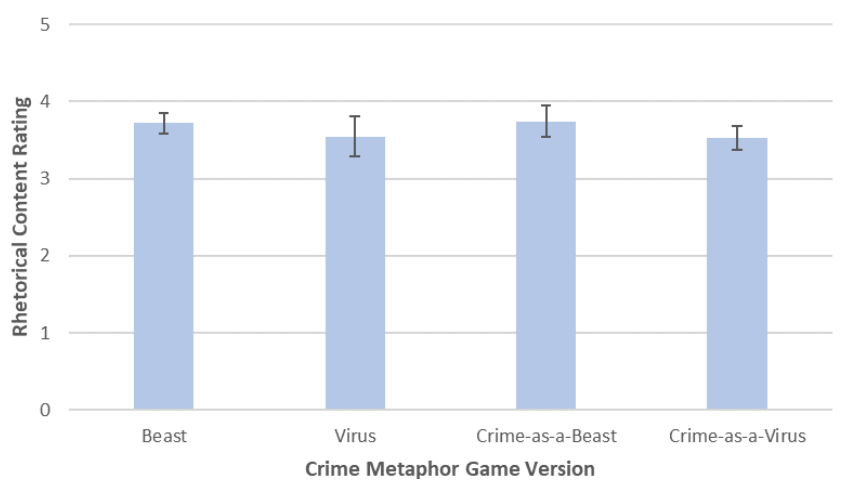

Figure 4: Rhetorical content rating did not vary across Crime Metaphor Game versions.

\begin{tabular}{|c|c|}
\hline Category & Example Responses \\
\hline Pro-prevention & $\begin{array}{l}\text { "Increase education and community involvement" } \\
\text { "Making more after school programs for kids to spend their time } \\
\text { doing more productive activities is what keeps that } \\
\text { neighborhood safe" }\end{array}$ \\
\hline Pro-enforcement & $\begin{array}{l}\text { "creating reform programs isn't as good as increasing patrols" } \\
\text { "more enforcement leads to safety" }\end{array}$ \\
\hline $\begin{array}{l}\text { Anti- } \\
\text { enforcement }\end{array}$ & $\begin{array}{l}\text { "Harsher tactics do not work" } \\
\text { "increasing raids and police activity actually makes the } \\
\text { neighborhood unsafe" }\end{array}$ \\
\hline Balance & $\begin{array}{l}\text { "It was trying to persuade how safer it will be using certain } \\
\text { methods to decrease the rate of crime, however they cost more." } \\
\text { "there needs to be a balance of what types of fights to fight in } \\
\text { certain cities" }\end{array}$ \\
\hline \multicolumn{2}{|c|}{$\begin{array}{l}\text { Table 3: Crime Metaphor Game. "What argument was the } \\
\text { game making?" example qualitative responses from top cat- } \\
\text { egories. }\end{array}$} \\
\hline
\end{tabular}




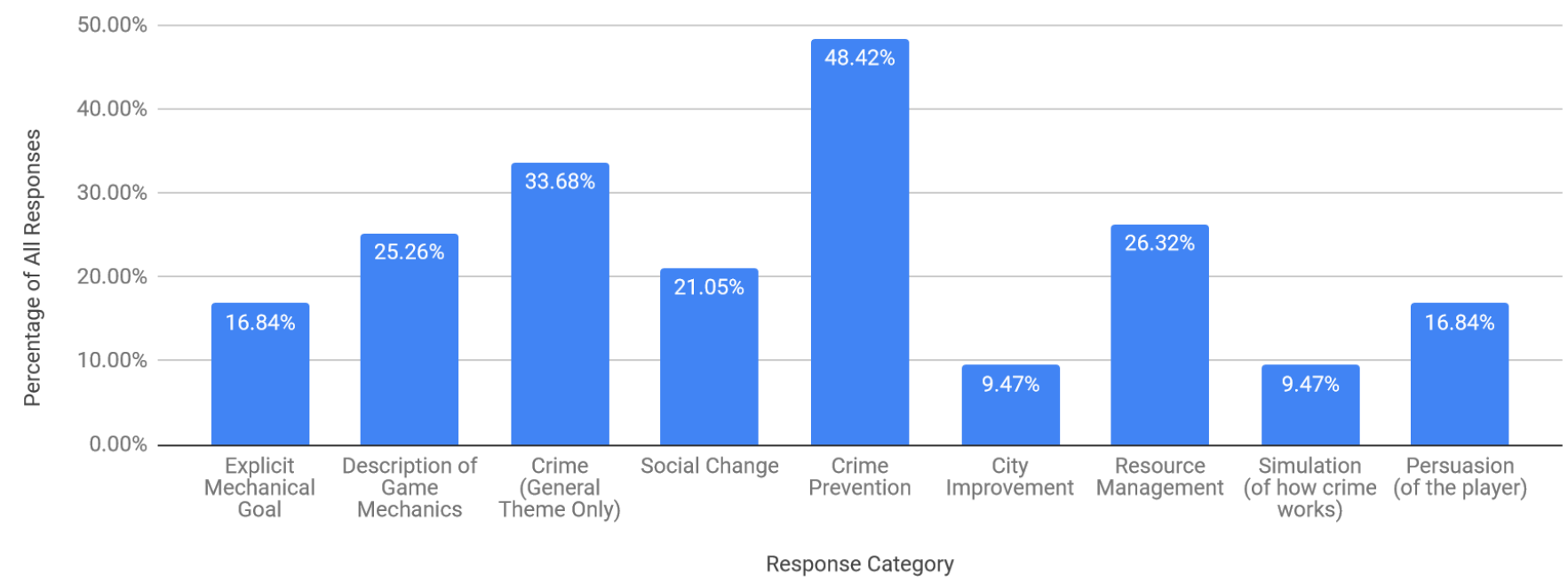

Figure 5: Crime Metaphor Game. “What was the game about?” qualitative responses for all game versions.

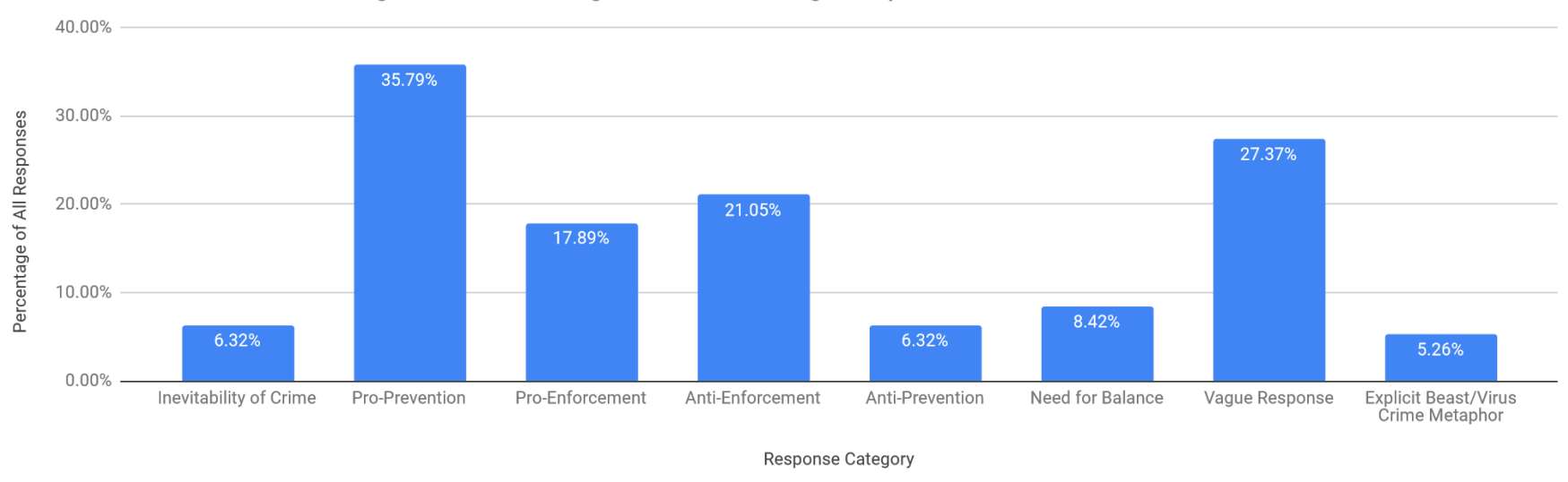

Figure 6: Crime Metaphor Game. "What argument was the game making?" qualitative responses for all game versions.

order to answer the second part of this question we compared participant's readings against our intended reading (See Table 3).

For the "What was the game about?" question, about half of players identified the game as being about "Crime Prevention" (48.42\%), which was the most common category. About a third of the participants identified it as making an explicitly pro-prevention argument (35.79\%), and about a third identified the general theme of "Crime," without the prevention connotation (See Fig.5). Responses to the "What argument was the game making?" question were more varied, with the top response category "Pro-Prevention" accounting for only about a third of responses. A small number of participants (5.26\%) explicitly identified the beast/virus crime metaphor (See Fig.6).

\subsection{Q3. Did differences in game mechanics or in narrative content change the perceived argument?}

To answer this question, we compared responses counts for each category across different game conditions. These counts did not vary by game condition, with one exception. Responses in the two mechanically consistent conditions (i.e. where the game mechanics did not vary) were more likely to refer to the explicit mechanical goals of the game (24\% in the Beast -> Crime-as-a-Beast condition and $40 \%$ in the Virus -> Crime-as-a-Virus condition), than responses in the mechanically inconsistent conditions (7\% for Beast $->$ Crimeas-a-Virus and $0 \%$ for Virus -> Crime-as-a-Beast), Chi-square (3) $=7.98, p=.047$. Overall, there too little variation between our experimental conditions for us to answer this research question. We cannot identify narrative framing or mechanics as the source of a difference, because we did not observe any difference at all. 




Figure 7: Changes in criminality attribution (external vs. internal) before and after playing Crime Metaphor Game versions did not appear to vary between game versions.

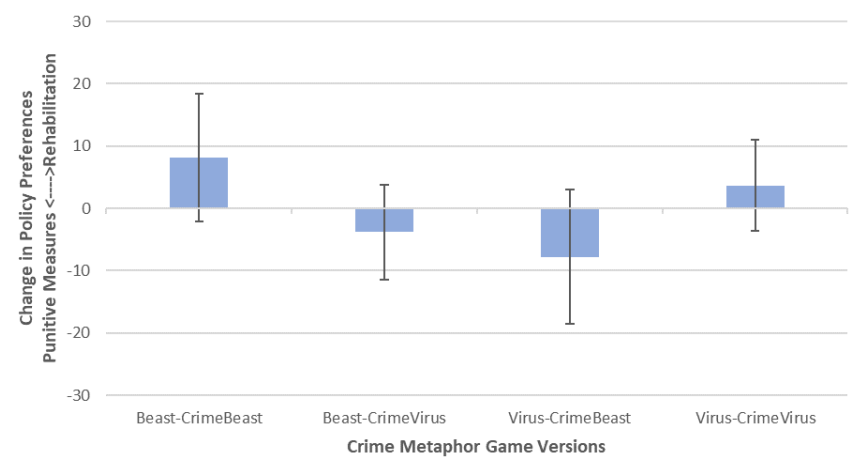

Figure 8: Rehabilitation (vs. punitive) spending preferences before and after Crime Metaphor Game versions did not appear to vary between game versions.



Figure 9: In-game enforcement spending was greater for Crime Metaphor Game versions with Virus mechanics.

\subsection{Q4. Did playing the game result in any change in the participants behavior or values, as it related to the game's content?}

This did not appear to be the case. We observed no effect of game condition on change in criminality attribution (internal/individual vs. external/situation), ("Beast" -> "Crime-as-a-Beast": $M=-.64 \%$, $S D=7.51 \%$, "Beast" -> "Crime-as-a-Virus": $M=-1.21 \%, S D=9.46 \%$, "Virus" -> "Crime-as-a-Beast": $M=9.51 \%, S D=31.14 \%$, "Virus" -> "Crime-as-a-Virus": $M=1.30 \%, S D=4.31 \%), F(3,77)=1.877, p=$ .141,(See Fig.7). Inclusion of media criticality as a covariate did not change the significance of this or any subsequent result.

Conducting a similar analysis, we did not observe any effect of game version on changes in preferences for how resources should be devoted to rehabilitative vs. punitive measures ("Beast" and "Crime-as-a-Beast": $M=8.14 \%, S D=26.62 \%$, "Beast" -> "Crime-asa-Virus": $M=-3.83 \%, S D=18.27 \%$, "Virus" -> "Crime-as-a-Beast": $M=-7.78 \%, S D=17.41 \%$, "Virus" -> "Crime-as-a-Virus": $M=3.65 \%$, $S D=11.81 \%), F(3,64)=1.99, p=.125$,(See Fig.8).

Participants' policy preferences for spending on prevention (vs enforcement) in the real world generally did not predict their spending in the game (where actions were also coded as prevention or enforcement), (Beast $r(66)=-.003$, Crime-as-a-Beast $r(45)=.425, p=$ $.004 p=.979$, Virus $r(29)=-.110, p=.571$, Crime-as-a-Virus $r(50)=.232$, $p=.105)$. The only exception was the Crime-as-a-Beast version of the game.

Enforcement vs. prevention spending in-game was predicted by the mechanics of the game. There was more enforcement spending in the Virus game version $(M=14.47, S D=8.80)$ than in the Beast game version $(M=8.10, S D=5.12), t(95)=4.477, p<.001$. Likewise, there was more enforcement spending in the Crime-as-a-Virus game version $(M=13.35, S D=7.38)$ than in the Crime-as-a-Beast game version $(M=7.00, S D=5.22), t(95)=4.847, p<.001$. Across these comparisons, we observed more enforcement spending in both game versions with Virus mechanics (See Fig.9).

Participants' spending on prevention vs. enforcement actions in the explicitly crime themed game versions predicted the real-world spending preferences they expressed after the game, (Crime-as-aBeast $r(46)=.486, p=.001$, Crime-as-a-Virus $r(51)=.278, p=.048$ ). We did not observe these correlations for the non-crime themed game versions (Beast $r(67)=.076, p=.539$, Virus $r(28)=-.135, p=$ .494). In short, participants who chose to take more enforcement actions in-game (in the crime themed games only) also expressed preferences for increased spending in the real world on enforcement in the post-game questionnaire, (See Fig.10).

\section{DISCUSSION AND CONCLUSIONS}

We examined the psychological effect of a persuasive game that we created, in an attempt to experimentally separate the impact of procedural and non-procedural elements of rhetoric. Our results suggest that it is possible to create a game that is perceived as rhetorical and that can convey the general context of an argument, but also that (even after expert feedback and design refinement) players' personal interpretations can be challenging to anticipate. We also found that the actions that players took within a game were predicted by the game's mechanics, more than by their pre-existing real world beliefs (in the form of policy preferences). However, after play those beliefs shifted in ways that were consistent with the player's in-game actions, for those games where this connection was clear. In short, preferences did not predict in-game actions, but in-game actions did predict subsequently expressed preferences. 


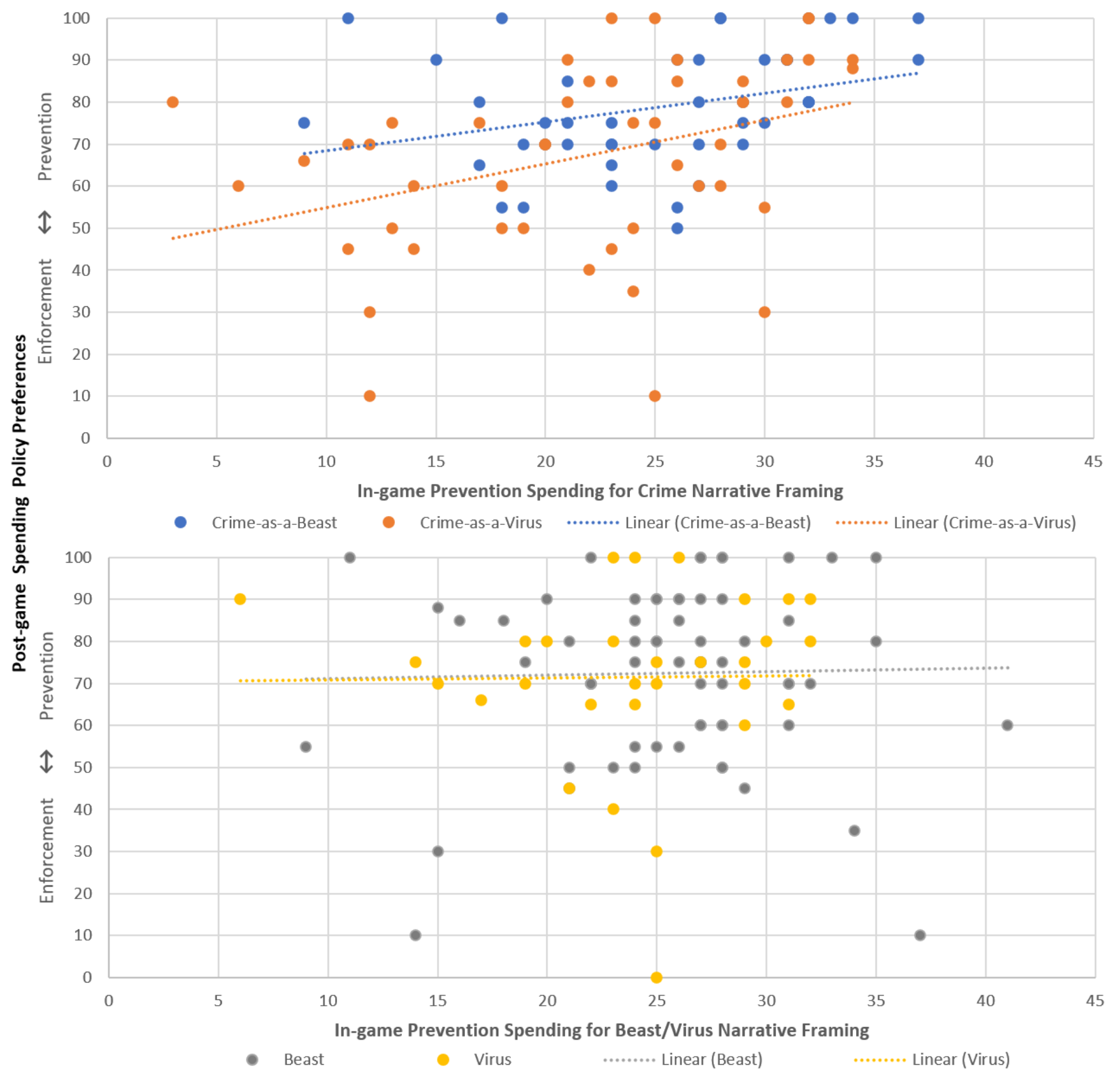

Figure 10: In-game enforcement actions for crime-themed versions of the Crime Metaphor Game correlated with post-game preferences for spending on enforcement.

\subsection{Summary of Results}

We observed qualified evidence for the effectiveness of our persuasive game. Its persuasive content was grounded in the strategies discovered by our players, rather than in our intentions as designers. And it was effective only when it was direct, combining game mechanical incentives with a clear and unambiguous theme.
Our first research question asked if players would perceive our persuasive games as having any rhetorical content and we found, consistent with our hypothesis, that generally they did. Participants rated our game for its degree of rhetorical content, and its rating was similar to that of other persuasive games [1]. These responses confirmed that we were achieving a rhetorical effect, and were a necessary prerequisite for our next research question. 
Our second research question asked if participants' perception of the game's rhetoric matched what we expected, and we hypothesized that they would. Here we saw that about half of players identified the game as being about crime prevention, and about a third identified it as making an explicitly pro-prevention argument, which is consistent with our hypothesis.

Our third research question asked if players' interpretations varied based on differences in procedural or non-procedural content. We hypothesized that our different game versions would lead to different interpretations, but none of the differences that we observed between game conditions reached a reportable level of statistical significance. With no observed effect of game condition, there was nothing to tease apart to be able to better answer this question.

Our fourth research question asked if the game had any influence on players' attitudes or beliefs related to its rhetorical content. We did not observe a statistically significant difference between participants' attitudes or policy preferences after play.

Overall, participants understood the context of the argument, but were often not explicitly aware of the specific point that we intended the game to be making within that context. They could identify the game as being about crime prevention, but differences in theme or mechanics were not read as different policy recommendations. It is not clear whether this gap is more reflective of our player's degree of critical engagement, or of the limitations of our abilities as game authors to achieve our intended rhetoric.

In looking at the behavioral data recorded in the game play traces we also observed that it was the mechanics of the game, not participant's stated policy preferences, that predicted their in-game actions. Those in-game actions did, however, predict changes in policy preferences after play. Players who took more enforcement actions in the game, driven by mechanics that rewarded those actions, reported greater support for enforcement policy after play. In short, player actions didn't reflect their beliefs, but their beliefs shifted to match their actions.

\subsection{Challenges and Limitations}

One of the major challenges of this kind of investigation is in anticipating player readings. In retrospect, there may have been mechanics that would have more effectively conveyed our intended meaning. From observation, the optimal strategy for the Beast or Crime-as-a-Beast game versions was to frontload enforcement actions, removing the source of mayhem/crime, and spend the rest of the game cleaning up with prevention actions. In the Crime-asa-Virus game, with no way to remove the source of crime/virus, the optimal strategy was to carefully balance actions between enforcement and prevention. The latter strategy was more difficult to discover than the former. Neither strategy can simply be reduced to a pure pro-prevention or pro-enforcement argument, and the mixed results on simpler questions may reflect this complexity.

We focused on the play trace record of a player's in-game actions and their subsequent interpretations of the game's meaning in our analyses. This could have been supplemented by a player's description of their experience, either during play (e.g. 'talk-aloud'), or in a self-report after play.

This work was conducted with several versions of a single persuasive game, addressing one specific context (crime prevention), using a small number of themes and rule sets. Any generalization of our findings will be tentative until a variety of additional games have been investigated, including those not explicitly created for research. The research context might also create response biases by implication, because it is not a naturalistic game play context, but that has to be weighed against the advantages of a controlled environment and detailed data collection.

Understanding a persuasive game's message is a complex interactive process that can also be specific to the experiences of an individual player. Expert evaluation can help, but the overall picture of both possible and likely readings will not emerge without exposing a game to a greater number and variety of players.

\subsection{Implications and Future Directions}

While we may not have been able to tease apart the exact nature of our Crime Metaphor Game's influence, we did observe that it had an impact on some of our participants' perceptions. This is more effective than typical examples of analogical transfer in the psychological literature $[11,15]$, which usually require explicit cues to encourage participants to link source and target domains, and should continue to be investigated.

Another major take-away here is the value of instrumenting a game for research purposes. We were able to observe the interesting interaction between in-game actions and policy preferences only because our game was designed to create a trace of each individual action. Future studies would benefit from games designed in such a way, or in engines or tools that make it possible to collect this kind of moment-to-moment interaction information from games created for non-research purposes. One of the hallmarks of interactive media is that an individual player is likely to only experience some subset of a game's possible moments, and that those moments might vary from player to player. Any exploration of a game's psychological impact would benefit from a system that makes it easier to tease apart these nuances.

We also hope that future work might use a similar design and approach with more popular games, to develop a nuanced understanding of their impact. For many, games are formative experiences, and there is value in understanding how they have shaped their players' visions of the world. Even without such a study, our work has implications for game developers, adding weight to the argument that their game mechanics design choices have important stakes, and encouraging them to think seriously about the actions and perspectives that those choices are supporting.

\section{ACKNOWLEDGMENTS}

The authors are grateful to Elizabeth Swensen and Jennifer Day for their advice on the design of this study, to Dr. Nicholas Davidenko and Dr. Katherine Isbister for presentation feedback, and to Dr. Benjamin Storm for access to lab facilities, Batu Aytemiz, Melanie Dickinson, Kavi Duvvoori, Cyril Focht, Katherine Green, Rich Grillotti, Jesse Harder, Nick Junius, Isaac Karth, Max Kreminski, Yanzi Li, Jordan Magnuson, Avital Meshi, Zoe Sandoval, Christine Starr, and Lee Taber provided invaluable critique of several early versions of our game. Thanks also to UCSC SIP interns Diego Bazan, Shangfeihong Cao, Kalie Ching, Yinghung (Claire) Ko, May Li, and Ashir Raza, for their assistance with data collection. 


\section{REFERENCES}

[1] Barrett R. Anderson, Chrisotpher Karzmark, and Noah Wardrip-Fruin. 2019. The Psychological Reality of Procedural Rhetoric. In Proceedings of the 14th International Conference on the Foundations of Digital Games (San Luis Obispo, California) (FDG'19).

[2] Entertainment Software Association. 2014. Essential facts about the computer and video game industry. 2014. (2014). http://www.theesa.com/wp-content/ uploads/2014/10/ESA_EF_2014.pdf

[3] Hans-Joachim Backe. 2017. Within the mainstream: an ecocritical framework for digital game history. Econzon@ 8, 2 (2017), 39-55. ISBN: 2171-9594 Publisher Universidad de Alcalá

[4] Lawrence W. Barsalou. 2008. Grounded cognition. Annu. Rev. Psychol. 59 (2008) 617-645.

[5] Lawrence W. Barsalou. 2010. Grounded cognition: Past, present, and future. Topics in cognitive science 2, 4 (2010), 716-724.

[6] Ian Bogost. 2007. Persuasive Games: the Expressive Power of Videogames. MIT Press.

[7] Italo Calvino. 1974. Invisible cities (first harvest/hbj edition. ed.). Harcourt Brace Jovanovich, New York.

[8] John S. Carroll, William T. Perkowitz, Arthur J. Lurigio, and Frances M. Weaver 1987. Sentencing goals, causal attributions, ideology, and personality. Fournal of Personality and Social Psychology 52, 1 (1987), 107-118. https://doi.org/10.1037/ 0022-3514.52.1.107

[9] Samuel B. Day and Robert L Goldstone 2011. Analogical transfer from a simulated physical system. fournal of Experimental Psychology: Learning, Memory, and Cognition 37, 3 (2011), 551. http://psycnet.apa.org/journals/xlm/37/3/551/

[10] Kevin Dunbar and Isabelle Blanchette. 2001. The in vivo/in vitro approach to cognition: The case of analogy. Trends in cognitive sciences 5, 8 (2001), 334-339.

[11] Dedre Gentner, Keith James Holyoak, and Boicho N. Kokinov. 2001. The analogical mind: Perspectives from cognitive science. MIT press.

[12] Mary L. Gick and Keith J. Holyoak. 1983. Schema induction and analogical transfer. Cognitive psychology 15, 1 (1983), 1-38.

[13] Barney G. Glaser. 1992. Basics of grounded theory analysis: Emergence vs forcing. Sociology press.

[14] Clint Hocking. [n.d.]. Ludonarrative Dissonance in Bioshock. https://clicknothing. typepad.com/click_nothing/2007/10/ludonarrative-d.html

[15] Douglas R. Hofstadter. 2001. Analogy as the core of cognition. The analogical mind: Perspectives from cognitive science (2001), 499-538.

[16] Keith J. Holyoak, Keith James Holyoak, and Paul Thagard. 1996. Mental leaps: Analogy in creative thought. MIT press.

[17] Keith J. Holyoak and Kyunghee Koh. 1987. Surface and structural similarity in analogical transfer. Memory \& cognition 15, 4 (1987), 332-340.

[18] Eliza Kitis and Michalis Milapides. 1997. Read it and believe it: How metaphor constructs ideology in news discourse. A case study. Fournal of Pragmatics 28, 5 (1997), 557-590. ISBN: 0378-2166 Publisher: North-Holland.

[19] George Lakoff. 1987. Women, fire, and dangerous things: What categories reveal about the mind. University of Chicago Press, Chicago, IL.

[20] George Lakoff and Mark Johnson. 1980. Metaphors we live by. Chicago: University of Chicago Press London.

[21] George Lakoff and Mark Johnson. 1999. Philosophy in the Flesh. Vol. 4. New york: Basic books.

[22] Matt Leacock. 2007. Pandemic [boardgame].

[23] Jack Lule. 2004. War and its metaphors: news language and the prelude to war in Iraq, 2003. Journalism Studies 5, 2 (2004), 179-190. ISBN: 1461-670X Publisher: Taylor \& Francis

[24] Roman Mars. 2019. Model City. https://99percentinvisible.org/episode/modelcity/ Library Catalog: 99percentinvisible.org Section: Cities.

[25] Laura R. Novick. 1988. Analogical transfer, problem similarity, and expertise fournal of Experimental Psychology: Learning, Memory, and Cognition 14, 3 (1988) 510

[26] Paolo Pedercini. 2014. MultipliCITY. https://www.molleindustria.org/blog/ multiplicity/ Library Catalog: www.molleindustria.org.

[27] Mary Pilon. 2015. The Monopolists: Obsession, Fury, and the Scandal Behind the World's Favorite Board Game. Bloomsbury Publishing USA.

[28] Otto Santa Ana. 1999. 'Like an Animal I was Treated': Anti-Immigrant Metaphor in US Public Discourse:. Discourse \& Society 10, 2 (April 1999). https://doi.org/ 10.1177/0957926599010002004 Publisher: SAGE Publications.

[29] Miguel Sicart. 2011. Against Procedurality. Game Studies 11, 3 (Dec. 2011). http://gamestudies.org/1103/articles/sicart_ap

[30] Paul H. Thibodeau and Lera Boroditsky. 2011. Metaphors we think with: The role of metaphor in reasoning. PloS one 6, 2 (2011), e16782.

[31] Paul H. Thibodeau and Lera Boroditsky. 2013. Natural language metaphors covertly influence reasoning. PloS one 8, 1 (2013), e52961.

[32] Mike Treanor, Bobby Schweizer, Ian Bogost, and Michael Mateas. 2011. Proceduralist Readings: How to Find Meaning in Games with Graphical Logics. In Proceedings of the 6th International Conference on Foundations of Digital Games (FDG '11) ACM, New York, NY, USA, 115-122. https://doi.org/10.1145/2159365.2159381
[33] Noah Wardrip-Fruin. 2007. Three Play Effects: Eliza, Tale-Spin, and Sim City. Digital Humanities (2007) 